\title{
Psychosocial impairment in children with Celiac disease.
}

1. MBBS, MCPS, FCPS (Pediatrics) Assistant Professor Developmental Pediatrics

The Institute of Child Health Multan. 2. MBBS, FCPS

Associate Professor Pediatric Gastroenterologist

The Institute of Child Health Multan.

3. MBBS, FCPS (Pediatrics)

Assistant Professor Pediatric

Gastroenterologist

The Institute of Child Health Multan.

4. MBBS

Postgraduate Registrar General Medicine

The Institute of Child Health Multan.

Correspondence Address:

Dr. Erum Afzal

Department of Developmental

Pediatrics

The Children Hospital and

The Institute of Child Health Multan.

erumafzal@yahoo.com

Article received on:

10/10/2020

Accepted for publication:

$12 / 02 / 2021$
Erum Afzal ${ }^{1}$, Aslam Sheikh², Ghazi Khan Khosa ${ }^{3}$, Komal Noor ${ }^{4}$

ABSTRACT... Objective: To determine the frequency of psychosocial impairment in patients with celiac disease. Study Design: Descriptive Cross Sectional study. Setting: Children Hospital Complex and Institute of Child Health, (CHICH) Multan. Period: August 2019 to August 2020. Material \& Methods: A total number of 177 patients having age 4-16 years with diagnosis of $C D$ were included in this study. In children with $C D$ depressive illness were assessed by using Pediatric symptoms checklist (PSC) form and this PSC form was filled by asking questions from parents then filling of form by doctor. Outcome variable was calculated on the basis of Pediatric symptoms checklist (PSC), whether patient has psychosocial illness or not. Results: Mean age of patients was $8.91 \pm 3.50$ years. Mean duration of celiac disease of patients was $4.27 \pm 2.00$ months. There were $135(76.27 \%)$ female patients and $42(23.73 \%)$ male patients. Mean serum anti-tissue transglutaminase IgA (tTG-IgA) level of patients was $122.73 \pm 24.31 \mu \mathrm{g} /$ $\mathrm{ml}$. The socioeconomic status of $115(64.97 \%)$ patients was poor, $31(17.51 \%)$ was middle, 18 (10.17\%) patient was upper middle and 13 (7.34\%) patients was high. Psychosocial illness was present in 35 (19.77\%) patients. Conclusion: Psychosocial illness was diagnosed in 19.77\% children having CD. So the children with celiac disease should be monitored for symptoms of anxiety and depression and a thorough counselling of the children to reduce the risk of psychosocial illness.

Key words: Celiac Disease, Psychosocial IIIness, Growth Retardation.

Article Citation: Afzal E, Sheikh A, Khosa GK, Noor K. Psychosocial impairment in children with Celiac disease. Professional Med J 2021; 28(10):1484-1488. https://doi.org/10.29309/TPMJ/2021.28.10.6142

\section{INTRODUCTION}

CD (Celiac Disease) is defined as "a chronic small intestinal immune mediated enteropathy precipitated by exposure to dietary gluten protein in genetically predisposed individuals"..,2 Gluten is a protein which is found in Rye, Barley, and Wheat. ${ }^{3}$ The worldwide prevalence of CD is $1 \%{ }^{4}$ In India it is around $3 \% .^{5}$ But in Pakistan it is largely unknown. ${ }^{6}$

American association of pediatrics (AAP) recommends anti-tissue transglutaminase $\lg A$ (tTG-lgA) level as best test for diagnosis of celiac disease and jejunal biopsy for confirmation of doubtful cases along with clinical features. ${ }^{7}$ The commonest complications of $\mathrm{CD}$ include Chronic diarrhea, Irritable bowel syndrome, Psychosocial impairment, Pruritus, fatigue and bloating. ${ }^{8} \mathrm{~A}$ high incidence of psychological impairment has been found in CD patients instead of a strict dietary management. It has been reported about 13.84\% by Rubio-Tapia. ${ }^{9}$ If a disease manifest early, it more affects the physical and psychosocial development of the child. Bystrom IM described that physical, psychological and social stress is more observed in children with chronic ailment like CD. 10

Pediatric Symptom Checklist (PSC) is a best tool for the assessment of psychosocial impairment in children more than 4 years of age. PSC has been demonstrated for identification of psychosocial problems (cognitive, emotional and behavioral). It is established by Jellinek, et al as screening tool for psychological and behavioral problems in children with fair validity and reliability. PSC consists of 35 items. These are scored and rated as 0 for "Never," 1 for "Sometimes," or 2 for "Often" respectively depending upon symptoms present. The total score is calculated by adding 
together the score for each item. A cutoff score of 28 or higher indicates psychological impairment for children and adolescents ages 6 through 16, While 24 or higher is significant. For 4 and $5 y e a r s$. If four or more items left blank (0-score), the questionnaire is considered invalid. ${ }^{11,12}$

Aim of my research was to know the prevalence of psychosocial impairment in children with CD, as No study about this problem has been done in Pakistan.CD patients faced more physical, and psychosocial stress as compared to healthy children $^{12}$, so management of this aspect must be started immediately to decrease the burden on family.

\section{MATERIAL \& METHODS}

This Cross sectional study was done in Developmental pediatric department with collaboration of Gastroenterology department of $\mathrm{CHICH}$ Multan from August-2019 to August 2020.A total 177 children diagnosed as CD ,4-6years of age, of both gender was included in this study. Sample size was calculated by using Non probability consecutive sampling (By taking the prevalence of depressive illness $65.67 \%$ by Rubio-Tapia ${ }^{10}$, margin of error $7 \%$, confidence level 95\%). The children with parental refusal, serum anti-tissue transglutaminase IgA (tTG-IgA) level with less than $50 \mathrm{ug} / \mathrm{ml}$, Depressive illness in the family (parents and siblings), any congenital anomaly like congenital heart defect. (Detected on Physical examination and appropriate investigations), and any other chronic illness like Tuberculosis (detected by history, examination or chest x-ray if needed) were excluded from the study.

Parents/guardian were detailed about the study and prior written consent was taken. The study was approved by institutional ethical committee (34/07/Ethical/CH\&ICH Multan). No conflict of interest was involved in this study. No financial support was provided by the institution or pharmaceutical company. A detailed history was taken from parents/guardian and patients. Patients with celiac disease were recruited from the Gastroenterology OPD and admitted children in ward according to the inclusion criteria. An informed consent was taken from the parents or guardian of patients after explaining nature of study, treatment and for using their data only for study. In patients celiac disease was diagnosed by tTG-IgA level. Socioeconomical status and Duration of illness was noted. Socioecononomical status was labelled on monthly income [(Poor ( $\leq 20000 /$ month), Middle (>20000-40000/ month), Upper Middle (>40000-60000/month), High ( $\geq 60000)$.

In patients with celiac disease depressive illness were assessed according to Pediatric symptoms checklist (PSC) form and this PSC form was filled by asking questions from parents then filling of form by doctor. This checklist facilitates the recognition of cognitive, emotional and behavioral problems.

Outcome variable on the basis of Pediatric symptoms checklist (PSC) was whether patient has psychosocial illness or not. All this information was collected and recorded on a predefined Performa. Due autonomy, beneficence, confidentiality and non-maleficence was ensured to the patients.

All the collected data was analyzed through SPSS version 16.0. Quantitative variables like age, duration of celiac disease, serum tTG-IgA level and Pediatric Symptom Checklist score was presented as mean and standard deviation. Qualitative variables like gender, socioeconomic status and psychosocial illness of the patient were presented in frequency and percentage. Effect modifier like age, gender, duration of celiac disease, Pediatric Symptom Checklist score, socioeconomic status and psychosocial illness of the patient were dealt through stratification. Chi square was applied to find $p$ value, which is considered significant if $\leq 0.05$.

\section{RESULTS}

Mean age of patients included in this study was $8.91 \pm 3.50$ years. Mean duration of celiac disease of patients was $4.27 \pm 2.00$ months. Mean serum anti-tissue transglutaminase $\operatorname{lgA}$ (tTG-lgA) level of patients was $122.73 \pm 24.31 \mu \mathrm{g} / \mathrm{ml}$. (Table-l). 
There were more females as compared to the males. There were 135 (76.27\%) female patients and $42(23.73 \%)$ male patients. On frequency of socioeconomic status, the socioeconomic status of $115(64.97 \%)$ patients were poor, 31 (17.51\%) was middle, 18 (10.17\%) patient was upper middle and 13 (7.34\%) patients were high. Psychosocial illness was present in 35 (19.77\%) patients versus it was found absent in $142(80.23 \%)$ patients (Table-II).

Stratification of age, gender, duration of celiac disease and socioeconomical status was performed, this difference of all was statistically insignificant, p-value of $0.883,0.232,0.770$ and0.469 respectfully. (Table-III)

\begin{tabular}{|c|c|c|c|}
\hline Variable & Mean \pm S.D & Minimum & Maximum \\
\hline Age (years) & $8.91 \pm 3.50$ & 04 & 16 \\
\hline $\begin{array}{l}\text { Duration of celiac } \\
\text { disease(months) }\end{array}$ & $4.27 \pm 2.00$ & 01 & 11 \\
\hline $\begin{array}{l}\text { Serum anti tissue } \\
\text { transglutaminase } \\
\text { lgA level(ug/ml) }\end{array}$ & $122.73 \pm 24.31$ & 90 & 250 \\
\hline \multicolumn{4}{|c|}{$\begin{array}{c}\text { Table-I. Descriptive statistics of quantitative } \\
\text { variables. }\end{array}$} \\
\hline \multicolumn{2}{|c|}{ Variable } & $\mathbf{N} \%$ & $\%$ \\
\hline \multirow{2}{*}{ Gender } & Male & 42 & 23.73 \\
\hline & Female & 135 & 76.27 \\
\hline \multirow{4}{*}{$\begin{array}{l}\text { Socioeconomic } \\
\text { status }\end{array}$} & Poor & 115 & 64.9 \\
\hline & Middle & 31 & 17.5 \\
\hline & Upper Middle & 18 & 10.17 \\
\hline & High & 13 & 7.34 \\
\hline \multirow{2}{*}{$\begin{array}{l}\text { Psychosocial } \\
\text { illness }\end{array}$} & Present & 35 & 19.77 \\
\hline & Absent & 142 & 80.23 \\
\hline
\end{tabular}

Table-II. Frequency of qualitative variables.

\section{DISCUSSION}

CD is an autoimmune disorder. In already predisposed person, when gluten is introduced in diet, it precipitates the manifestations of CD. The gluten is a protein mainly found in wheat and similar grains.CD now is one of most common pediatric malabsorption syndrome, which may be manifest at any age and its consequences includes Gastrointestinal, metabolic, nutritional and psychosocial impairment. ${ }^{13}$

\begin{tabular}{|c|c|c|c|}
\hline \multirow{2}{*}{ Variable } & \multicolumn{2}{|c|}{ Psychosocial IIIness } & \multirow{2}{*}{ P-Value } \\
\hline & Yes & No & \\
\hline $\begin{array}{l}\text { Age(years) } \\
4-8 \\
>8-16\end{array}$ & $\begin{array}{l}18 \\
17\end{array}$ & $\begin{array}{l}75 \\
67\end{array}$ & 0.883 \\
\hline $\begin{array}{l}\text { Gender } \\
\text { Male } \\
\text { Female }\end{array}$ & $\begin{array}{l}11 \\
24\end{array}$ & $\begin{array}{c}31 \\
111\end{array}$ & 0.232 \\
\hline $\begin{array}{l}\text { Duration of illness } \\
\text { (months) } \\
1-4 \\
>4-11\end{array}$ & $\begin{array}{l}20 \\
15\end{array}$ & $\begin{array}{l}85 \\
57\end{array}$ & 0.770 \\
\hline $\begin{array}{l}\text { Socioeconomic } \\
\text { status } \\
\text { Poor } \\
\text { Middle } \\
\text { Upper middle } \\
\text { High }\end{array}$ & $\begin{array}{l}22 \\
05 \\
06 \\
02\end{array}$ & $\begin{array}{l}93 \\
26 \\
12 \\
11\end{array}$ & 0.469 \\
\hline
\end{tabular}

In present study we determined the frequency of psychological disorders in children with diagnosis of CD. In present study, psychological illness was diagnosed in $19.77 \%$ patients of CD. Some case control and case series studies done by gastroenterologists described the depression as a symptom of CD. ${ }^{14}$ While the level of depression in CDs depends upon good medical management and strict dietary restriction is still under debate. Cohort study done by Ludvigsson JF and another by Siniscalchi $\mathrm{M}$ determined more depression in CDs compared to controls of the general population ${ }^{15,16}$, while Garud Sothers at USA found no difference. ${ }^{17}$ Similarly anxiety is reported as a common manifestation of CD patients by some researchers in case control studies, while some did not. ${ }^{18,19}$ In Italy and Scandinavia the $\mathrm{CD}$ children are found to be more prone for psychiatric disorders. ${ }^{20,21}$

We did not find any significant difference in the frequency of psychosocial illness in male and female patients. Similarly, study done in Italy, anxiety and depression is found to be not related to gender 22 While a study done in Scandinavian reported lower levels of psychosocial impairment 
in female CD patients. ${ }^{23}$

We also did not find any significant association between the duration of CD and psychosocial illness which is similar to the studies done in Italy. ${ }^{19,22}$ we found no significant association of duration of disease with psychosocial illness.

There are some limitations for this study, it was a cross-sectional study, and we did not take healthy controls and compared the frequency of psychosocial impairment in healthy controls of similar age. So there is a need to conduct a large multicenter case control study in our population to determine the exact prevalence of psychosocial illness in CD patients.

\section{CONCLUSION}

Psychosocial illness is very common in children with CD. So the children with $C D$ should be assessed periodically for symptoms of anxiety and depression and early counselling and psychotherapy of the children must be done to reduce the burden caused by psychosocial illness in the family.

Copyright@ 12 Feb, 2021.

\section{REFERENCES}

1. Ludvigsson JF, Leffler DA, Bai JC. The Oslo definitions for coeliac disease and related terms. Gut. 2013; $62(3): 43-52$.

2. Ludvigsson JF, Zingone F, Tomson T, Ekbom A, Ciacci C. Increased risk of epilepsy in biopsy-verified celiac disease: A population-based cohort study. Neurology. 2012; 78(18):1401-7.

3. Lamacchia C, Camarca A, Picascia S, Di Luccia A, Gianfrani. Cereal based gluten-free food: How to reconcile nutritional and technological properties of wheat proteins with safety for celiac disease patients. Nutrients. 2014; 6(2):575-90.

4. Babar MI, Ahmad I, Rao MS, Iqbal R, Asghar S, Saleem $\mathrm{S}$. Celiac disease and celiac crisis in children. J Coll Physicians Surg Pak. 2011; 21 (8):487-90.

5. Alvi MY, Abbas M, Ahmed M, Farooq A, Kazi M. Clinical presentation of celiac disease in children. Pak J Med Health Sci. 2010; 4(4):552-4.
6. Rabia M, Naeemullah S, Baqai MT, Shabbir A. Clinical presentations of coeliac disease in children from 2 to 14 years. JRMC. 2012; 16(2):112-4.

7. Mazzone L, Reale L, Spina M. Compliant glutenfree children with celiac disease: An evaluation of psychological distress. BMC Pediatrics. 2011; 46(1):11. Med Sci. 2014; 11(8):819-23.

8. Barratt SM1, Leeds JS, Sanders DS. Factors influencing the type, timing and severity of symptomatic responses to dietary gluten in patients with biopsy proven coeliac disease. J Gastrointestin Liver Dis. 2013; 22(4):391-6.

9. Rubio-Tapia A, Hill ID, Kelly CP, Calderwood AH, Murray JA. ACG clinical guidelines: Diagnosis and management of celiac disease. Am J Gastroenterol. 2013; 108(5):656-76.

10. Bystrom IM, Hollén E, Falth-Magnusson K, Johansson AK. Health related quality of life in children and adolescents with celiac disease: From the perspectives of children and parents. Gastroenterol Res Pract. 2012; 2012(8):986475.

11. Jellinek MS, Murphy JM, Little M. Use of the pediatric symptom checklist (psc) to screen for psychosocial problems in pediatric primary care: A national feasibility study. APAM. 1999; 153(3):254-60.

12. Little M, Murphy JM, Jellinek MS. Screening 4 and 5-year-old children for psychosocial dysfunction: A preliminary study with the Pediatric Symptom Checklist. JDBP.1994; 15(1):191-7.

13. Addolorato G, Leggio L, D'Angelo C, Mirijello A, Ferrulli A, Cardone S, et al. Affective and psychiatric disorders in celiac disease. Dig Dis. 2008; 26(1):140148.

14. Hallert C, Derefeldt T. Psychic disturbances in adult coeliac disease. I. Clinical observations. Scand J Gastroenterol. 1982; 17(1):17-19.

15. Ludvigsson JF, Reutfors J, Osby U, Ekbom A, Montgomery SM. Coeliac disease and risk of mood disorders--a general population-based cohort study. J Affect Disord. 2007; 99(2):117-126.

16. Siniscalchi M, lovino P, Tortora R, Forestiero S, Somma $A$, Capuano $L$, et al. Fatigue in adult coeliac disease. Aliment Pharmacol Ther. 2005; 22(3):489494.

17. Garud S, Leffler D, Dennis M, Edwards-George J, Saryan $D$, Sheth $S$, et al. Interaction between psychiatric and autoimmune disorders in coeliac disease patients in the Northeastern United States. Aliment Pharmacol Ther. 2009; 29(8):898-905. 
18. Addolorato G, Mirijello A, D’Angelo C, Leggio L, Ferrulli $A$, Vonghia $L$, et al. Social phobia in coeliac disease. Scand J Gastroenterol. 2008; 43(5):410-15.

19. Roos S, Kärner A, Hallert C. Psychological well-being of adult coeliac patients treated for 10 years. Dig Liver Dis. 2006; 38(1):177-180.

20. Carta MG, Hardoy MC, Boi MF, Mariotti S, Carpiniello $B$, Usai P. Association between panic disorder, major depressive disorder and celiac disease: A possible role of thyroid autoimmunity. J Psychosom Res. 2002; 53:789-793.
21. Butwicka A, Lichtenstein P, Frisén L, Almqvist $C$, Larsson $H$, Ludvigsson JF. Celiac disease is associated with childhood psychiatric disorders: A population-based study. J Pediatr. 2017; 184(1):87-93.

22. Ciacci C, D'Agate C, De Rosa A, Franzese C, Errichiello $\mathrm{S}$, Gasperi V, et al. Self-rated quality of life in celiac disease. Dig Dis Sci. 2003; 48(12):2216-20.

23. Hallert C, Sandlund O, Broqvist M. Perceptions of health-related quality of life of men and women living with coeliac disease. Scand J Caring Sci. 2003; 17(4):301-7.

\begin{tabular}{|c|l|l|l|}
\hline \multicolumn{2}{|c|}{ AUTHORSHIP AND CONTRIBUTION DECLARATION } \\
\hline Sr. \# & \multicolumn{1}{|c|}{ Author(s) Full Name } & \multicolumn{1}{|c|}{ Contribution to the paper } & Author(s) Signature \\
\hline 1 & Erum Afzal & $\begin{array}{l}\text { Literature search, Results, } \\
\text { Discussion, Final approval. } \\
\text { Literature search, study design, } \\
\text { data interpretation of final } \\
\text { approval. }\end{array}$ \\
\hline 3 & Aslam Sheikh & $\begin{array}{l}\text { Introduction, Results data, } \\
\text { Interpretation of final approval. } \\
\text { Literature search, Discussion of } \\
\text { final approval. }\end{array}$ & Khan Khosa \\
\hline 4 & Komal Noor & Karm \\
\hline
\end{tabular}

